\title{
Selected Key Issues in World Protests
}

Abstract This section of the book "World Protests: A Study of Key Protest Issues in the 21st-Century" analyzes: (i) trends such as the rise of populism and radical right protests; (ii) anti-corruption and women's protests; (iii) the link between inequality and protests, as well as the link between protests and perceptions that governments serve only the few; (iv) the Arab and the Latin American Springs; and (v) the link between protestors' policy demands, Human Rights and internationally agreed UN development goals, calling on governments to act on them.

Keywords Protests · Populism · Inequality · Women · Corruption · Human rights

\section{Rising Populism and Radical Right Protests}

\subsection{From Left-Wing to Far-Right Populist Protests}

In the fifteen years covered by this study, we saw an increasing number of protests driven by two different versions of populism, some considered left-wing and others right-wing. Moreover, this rising populism came in two distinct phases characterized by political orientation, the first of which was anti-authoritarian, and the second of which has been supportive of more authoritarian leaders. 
The first populist wave (2008-2012) was anti-authoritarian and driven by left-wing economic ideas. It was led by groups angry with the corruption of elites and stirred into action by hardships brought on by the commodity price spikes and financial crisis of 2008-2009. The 20102011 revolutions in Tunisia and Egypt, the social protests throughout Europe, especially southern Europe, that they inspired, and the Occupy Wall Street and Occupy Hong Kong movements of 2011-2013, are prime examples of this economic populism, which changed the debate about globalization and who gets to determine peoples' economic destiny (Ortiz et al., 2013). While left-wing protests were reduced somewhat by 2013-2014, their political benefits continued to accrue to left-wing parties, the most notable of which were Syriza in Greece, Podemos in Spain, and Morena in Mexico. New political movements also emerged, such as Our Revolution, led by democratic socialist Bernie Sanders in the United States.

The second populist wave (2013-present) was fueled even more than the first wave by the corruption of elites, but also by failed migration policies, especially in northern Europe, and by worsening inequalities. This second wave is marked by both nationalism and the condemnation of political systems, as well as allegations that dark forces in a "deep state" (or a "deep European/foreign powers" in the case of Hungary, Poland, the United Kingdom, and Turkey) conspire to deny economic security to middle classes in the face of globalization. While the anger of these populists may be a rational response to political systems that have failed for years to deliver on their economic needs (Bello, 2019; Bröning, 2016), the most unsettling characteristic of this populist wave is how many protesters demand not only their own rights, but to deny rights and equal status to groups they think threaten their jobs or status, such as immigrants.

This emphasis on denying rights reveals that populist uprisings became vulnerable to authoritarian influencers and right-wing propagandists, who have effectively instrumentalized populist energy. Anti-Muslim movements such as PEGIDA (Patriotic Europeans Against the Islamization of the Occident) in Germany, the "Leave" (the European Union) movement in Britain, rampant nationalism against foreign powers in Turkey, the "war on drugs" in the Philippines, or the cow "vigilantes" in India are prime examples of right-wing populist movements which have-in turn-energized the growth of right-wing nationalist political parties like Alternative für Deutschland in Germany, UKIP (Independence Party) in the United 


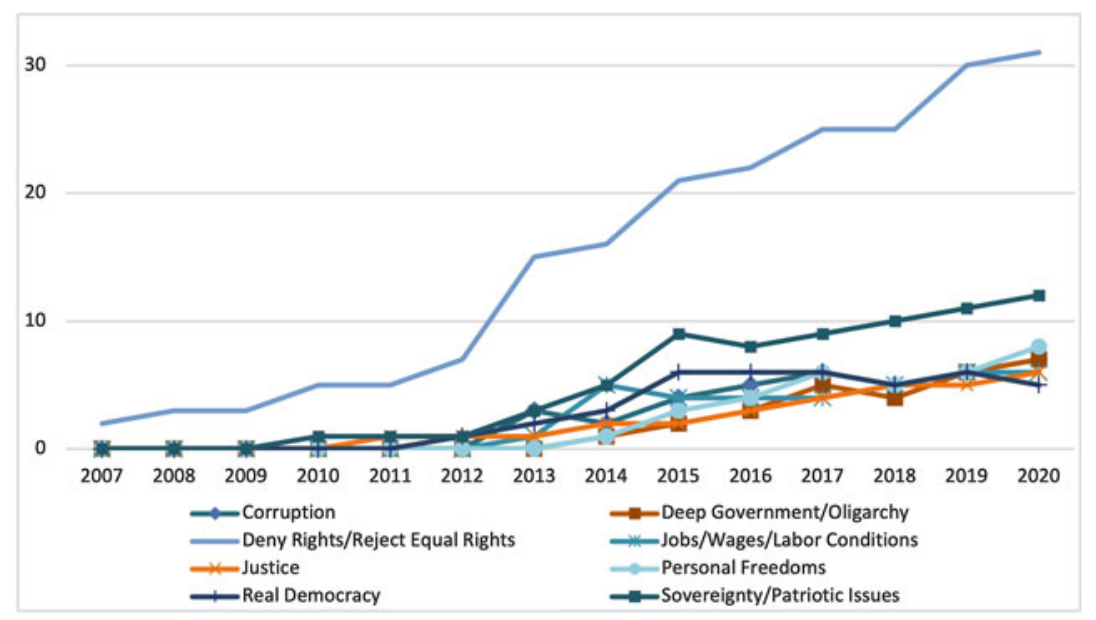

Fig. 1 Radical right protests: demands/grievances correlated with the denying of rights, 2006-2020 (Source Authors' analysis of world protests in media sources 2006-2020, see: https://worldprotests.org/)

Kingdom, Ak Parti in Turkey, and the BJP (Bharatiya Janata Party) in India.

It is instructive to look at the other demands and grievances found in protests alongside demands to deny rights. Figure 1 shows the set of demands most commonly associated with the denial of rights and/or the rejection of equal rights for a group. ${ }^{1}$ Chief among them are demands relating to sovereignty, nationalism, and patriotism, which are the most strongly correlated with rights-denial, as well as a cluster relating to personal freedoms, deep government/oligarchy, corruption, and real democracy. Slightly less numerous but still present are demands for jobs and justice.

In the first populist wave, when anti-authoritarianism and economic populism was in the ascendant, there were significantly fewer instances of protests to deny rights. Those instances came along most often with sovereignty and patriotic issues. Examples include dueling Serbian and

${ }^{1}$ Chapter 2, Fig. 21 lists only the number of times the included demands/grievances are found to contain denial of rights demands; other instances of these demands may be found in protests that do not demand rights-denial. 
Croatian nationalists protesting war crimes charges in 2011 and the harassment of Roma people in Hungary by nationalist Jobbik party patriots in 2012 .

It is striking in the second populist wave that protests to deny rights almost doubled, raising patriotic and nationalist demands in their wake. Cries for personal freedoms (to carry a gun, not to wear a mask, not to be quarantined) went along almost as often as patriotism with demands to deny rights, and conspiratorial beliefs in a "deep state" /deep foreign powers" as well as grudges against oligarchies and elites were also a strong part of this ethos. Examples can be seen in Erdogan's Muslim nationalism in Turkey; the calls for order and national conservatism by Bolsonaro in Brazil and Orban in Hungary; the "Revolution of the Pititas" movement in Bolivia against the re-election of President Morales; in the Italian "Orange Vests" movements, whose demands for jobs and affordable fuel have been replaced by protests against pandemic restrictions; and in the QAnon movement that embraces widespread conspiracy theories linked to the January 6, 2021 storming of the United States Capitol.

Anti-corruption protests increased sevenfold during the second wave. A key anti-corruption demand linked to demands for a denial of rights, and seen as early as mid-2013, implicates Brazil's neo-Pentecostal movement, which advanced their religious rights in alliance with the "Bullets, Bible and Beef" caucus in Congress to overturn the democraticallyelected Workers Party government by infiltrating and co-opting Brazil's burgeoning anti-corruption social movement. ${ }^{2}$ Another demand linked to rights denial that rose in importance was the demand for real democracy, which tripled. Examples include white nationalists in Australia ${ }^{3}$ and the United States who seek to block social participation by Muslim and non-white immigrants: these white nationalists cited their own democratic rights to have immigration law enforced (Rohac et al., 2018). Also, Canadal's 2015 anti-terrorism law limiting citizens' rights to protest and peacefully assemble was championed by some rights-deniers as a "defense of democracy." Demands for better jobs, wages, and labor conditions in the context of calls to deny rights also rose. Examples include Germany's

2 Bevins, V. 2018. "The Brazilian Spring that never arrived: How the hopeful protests of June 2013 were co-opted by forces intent on bringing down the left." The Atlantic, June 20, 2018.

3 See: Australian Associated Press (AAP) 2015. "Five arrested as reclaim Australia and anti-racism protesters face off in Sydney." The Guardian, July 19, 2015. 
PEGIDA movement, Britain's “leave" (the European Union) movement, Kyrgyzstan's anti-Chinese movement and "yellowvests" movements in France, Ireland, and Canada: all claimed immigrant labor would destroy domestic labor markets.

\subsection{Weaponizing Protests}

Now that we have taken note of the various demands and grievances that accompany rights denial, further context is needed to more fully understand what caused the dramatic shift from anti-authoritarian economic populism to generally authoritarian, denial-of-rights based populism. The sort of economic populism that propelled movements like Occupy Wall Street, with its demand to shatter the economic inequality between the $1 \%$ and the $99 \%$, went hand in hand with the movement's call for real democracy. Exuberant optimism and clever messaging spread the battle of the $99 \%$ against the $1 \%$ around the globe, and "occupies," where people assembled in streets and squares to debate how to build communities where everyone's voice could be heard, could be found from New York to Buenos Aires to Hong Kong.

The importance of this economic populism was a focus by the $99 \%$ on charting its own economic destiny by rooting out corruption, corporate influence, and the privilege of elites. They wanted to achieve "economic justice" with an inclusive vision of striving for the common needs of all the $99 \%$. This is the sort of populism that economic historian Thomas Frank says originated in the United States People's Party of the 1890s, which coined the term "populism" to describe its cross-racial and crossethnic organizing first principle: building an economy and society that tries to provide for the common needs of all groups (Frank, 2020).

However, by mid-2013, although the Occupy movement had changed the public debate regarding inequality, its energy had faded, and financial reform to address inequalities had been stymied by financial lobbyists and other forms of political capture (Cortés Saenz \& Itríago, 2018). At the same time, Egypt's democratically-elected successor to the revolution's overthrown autocrat had himself been overthrown in a military coup, and Tunisia's mostly nonviolent revolution was in crisis. Furthermore, the shipwreck of the fishing boat Lampedusa and the subsequent deaths of hundreds of Libyan, Somali, and Sudanese refugees and migrants in the Mediterranean off the Italian coast in mid-2013 set the stage for a rising migration crisis and calls to seal borders. With lingering economic 
pain due to rising living costs, poor wages, austerity cuts, and corruption, people around the world increasingly lost trust in elites, experts, globalization, and faceless institutions, a situation that was quickly exploited by authoritarian influencers.

There are many examples in history where the fears of lower and middle classes are manipulated by far right movements (Bello, 2019). Hardship makes people susceptible to race-baiting, ethnic or religious slurs, and misogyny. Today, these were the tactics employed as right-wing propaganda became "weaponized" by social media's algorithm-driven "rabbit holes," in which people seek out more and more conspiracy theories and extreme information the longer they stay engaged. The result, according to scholars like Tim Wu and Miguel Schor, has been the undermining of advantages that a commitment to free speech once gave democracies over authoritarianism. ${ }^{4}$ The cumulative effect is that people around the world are increasingly isolated in narrow "information bubbles," ensnared by social media business models developed within a United States legal landscape that does not hold Internet platforms responsible for what is published on them. The Internet influencers and autocrats who benefit from the climate of moral hazard caused by the lack of regulation of new media have also weaponized protests themselves, as demonstrated by the storming of the United States Capitol on January 6, 2021. These charismatic leaders are not populists; they are cynical antipopulists who seek to prevail through the peddling of lies (Frank, 2020). They take advantage of the fact that the problems caused by the 2008 financial crisis and the subsequent migration/refugee crisis, which set the stage for the present situation, have not been corrected, and have even been compounded in intensity since the COVID-19 pandemic began.

Thus in the period 2006-2020 we have seen protests being used by political factions to reach power, often encouraging violence. Foreign and national groups are increasingly meddling in national politics through the use of misinformation and disinformation. For example, Brannen et al. (2020) document Russian interference in other countries' internal affairs and elections by fomenting dissent through fake news and internet hate content, often through "troll farms." Other groups are also fostering animosity and weakening democracies to advance their interests, by weaponizing misinformation in social media, including but not limited

4 Edsall, T.B. 2021. "Have Trump's lies wrecked free speech?” New York Times, January 6,2021 . 
to radical right groups. For example, in 2020 multiple United States media outlets reported on white supremacist groups weaponizing protests against police brutality, inciting protesters to start violence. ${ }^{5}$

According to the 2020 Global Satisfaction with Democracy Report, almost $60 \%$ of people worldwide are dissatisfied with democracy; this means 1.4 billion people live in countries where democracy is in crisis or malaise (Foa et al., 2020). Sadly, the fracturing of information norms ("facts"), exemplified by the United States' Trump presidency, has eroded even further the common ground of agreement necessary for democracies to function. The underlying factors driving people into radical right movements-corruption, precarious employment, constrained social mobility and violated rights-are not improving fast enough to stop populism's authoritarian drift.

To counter radical right populism, societies will need to expose the contradictions of far-right politics, so that people can become aware of them, and they will also need to pursue a radically inclusive form of politics, open but not identitarian, with fair economic policies to reduce inequalities and offer opportunity and better living standards to all citizens. The world will not see a reversal of the trend towards authoritarian nationalist movements unless significant efforts are mounted to fight polarization, inequality, and disinformation. Such efforts would address many of the underlying grievances and yearnings of protesters, which-if ignored-will continue to draw the attention of radical right leaders who seek to divide and conquer.

\section{INEQUALITY}

\subsection{Inequality and Protests}

Across history, inequality has been considered the ultimate driver of protests. From Marx to Tocqueville, authors have written about inequality, injustice, rebellion, and protests. Today, inequality is staggering, estimated to be the highest in history (United Nations, 2020). As calculated by Oxfam (2020), the world's richest $1 \%$ have more than twice as much wealth as the remaining 6.9 billion people. In the United States,

5 Business Insider, June 2, 2020: "A white supremacist channel on Telegram encouraged followers to incite violence during police brutality protests by 'shooting in a crowd,' according to internal Department of Home Security memo." 
the three richest people have the same amount of wealth as the bottom 160 million. The middle classes have been shrinking in a majority of highincome countries (OECD, 2019), the result of four decades of neoliberal policies and a decade of austerity cuts (della Porta, 2017; Ortiz \& Cummins, 2019). Further, inequalities are increasing with the COVID19 pandemic; while millions of people are being forced into poverty, the richest individuals and corporations returned to their pre-pandemic highs in just nine months (Oxfam, 2021).

Looking at the number of protest and inequality Gini coefficients (after tax and benefits), our research corroborates a positive relation between higher levels of inequality and protests in high-income and middle-income countries (Figs. 2 and 3). However, this is not the case in low-income countries (Fig. 4).

Analyses of the relationship between inequality and political instability have produced a diverse and contradictory array of findings. While the impact of inequality on conflict is still being debated, this study evidences

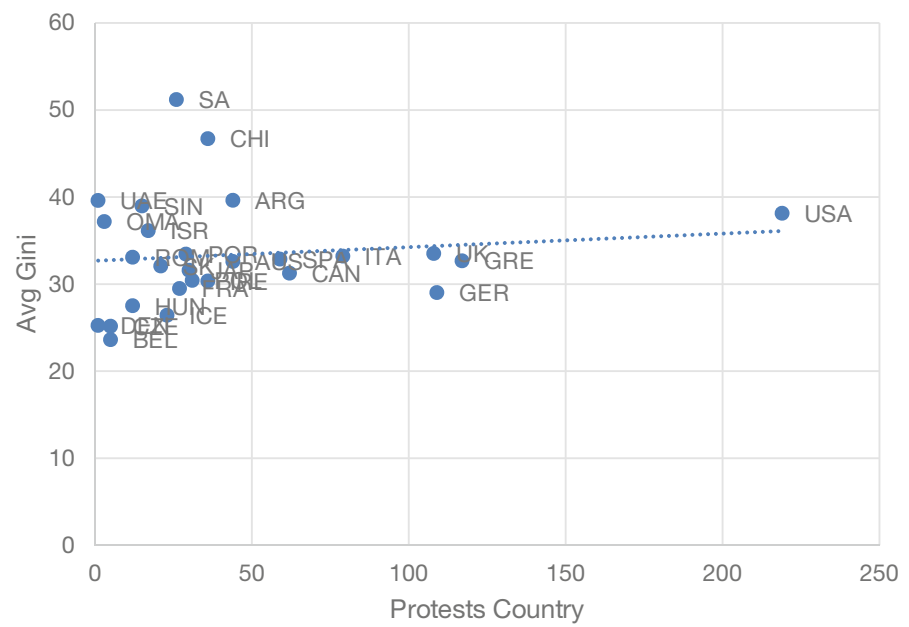

Fig. 2 Inequality and protests in high-income countries (Source Authors' analysis of world protests in media sources 2006-2020 and Solt, 2020) 


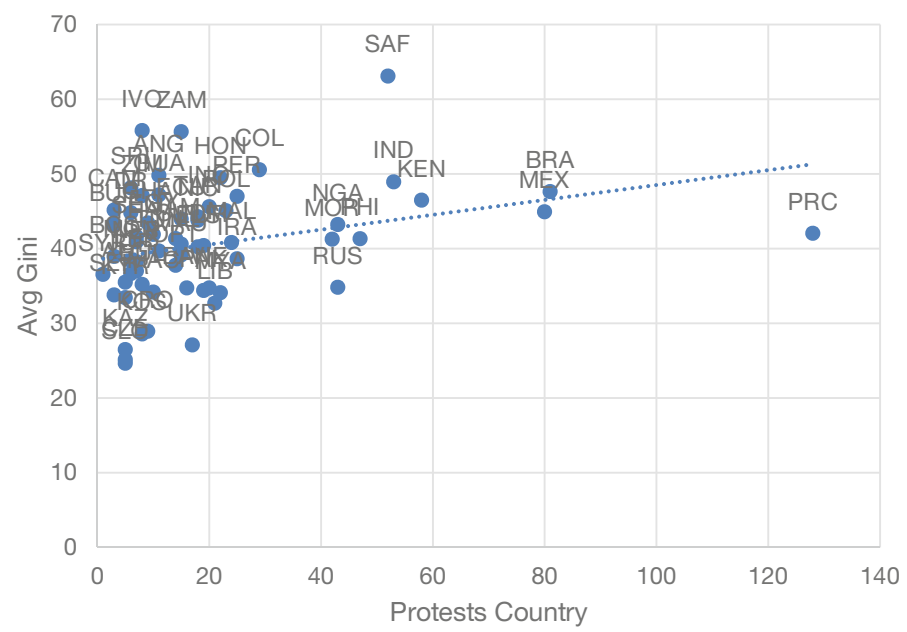

Fig. 3 Inequality and protests in middle-income countries, 2006-2020 (Source Authors' analysis of world protests in media sources 2006-2020 and Solt, 2020)

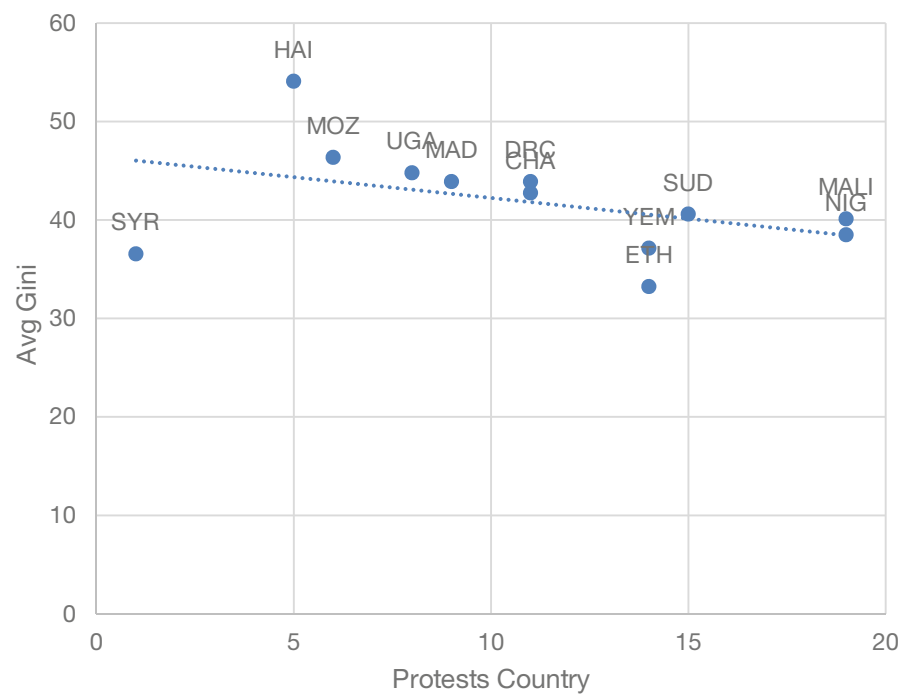

Fig. 4 Inequality and protests in low-income countries, 2006-2020 (Source Authors' analysis of world protests in media sources 2006-2020 and Solt, 2020) 


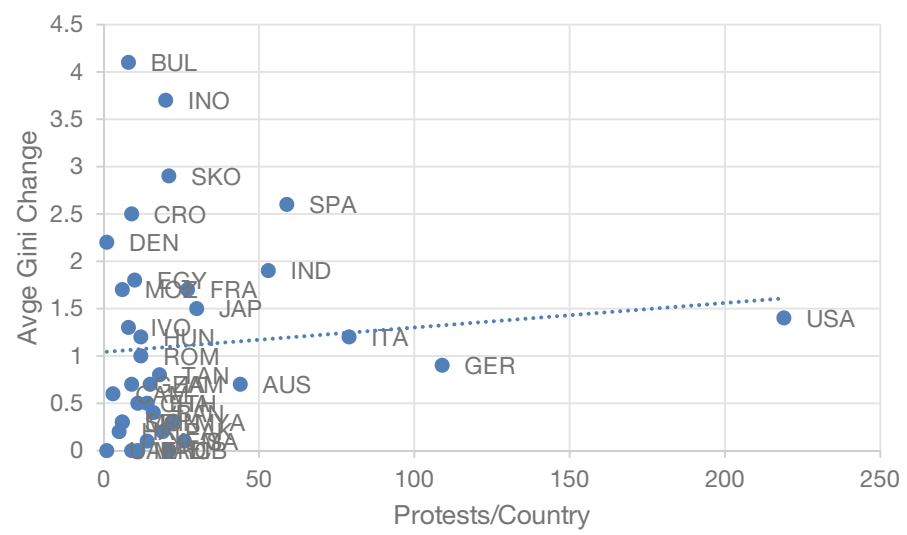

Fig. 5 Protests in countries with increasing inequality, 2006-2020 (Source Authors' analysis of world protests in media sources 2006-2020 and Solt, 2020)

a link between inequality and protests in high- and middle-income countries by looking at Gini coefficients (after tax and benefits) and numbers of protests, updating earlier research (Dubrow et al., 2008). ${ }^{6}$

To further explore the issue, we look at the relationship between protests and increases in inequality. Many commentators have pointed out that changes in inequality are just as important as levels of inequality-Tocqueville's argument that people rebel more when they perceive declines in their standards of living. Figures 5 and 6 show the relationship between protests and changes in inequality, measured by Gini coefficients (after tax and benefits). The trend lines show that there are more protests in countries with increasing inequality, and vice versa, fewer protests in countries in which inequality is being reduced.

${ }^{6}$ Other studies use other variables, for example, Collier and Hoeffler (2004) look at the relationship between gini coefficients on income inequality/land inequality and civil wars; MacCulloch (2005) examines Gini indices and the "preference for revolt" taken from surveys. 


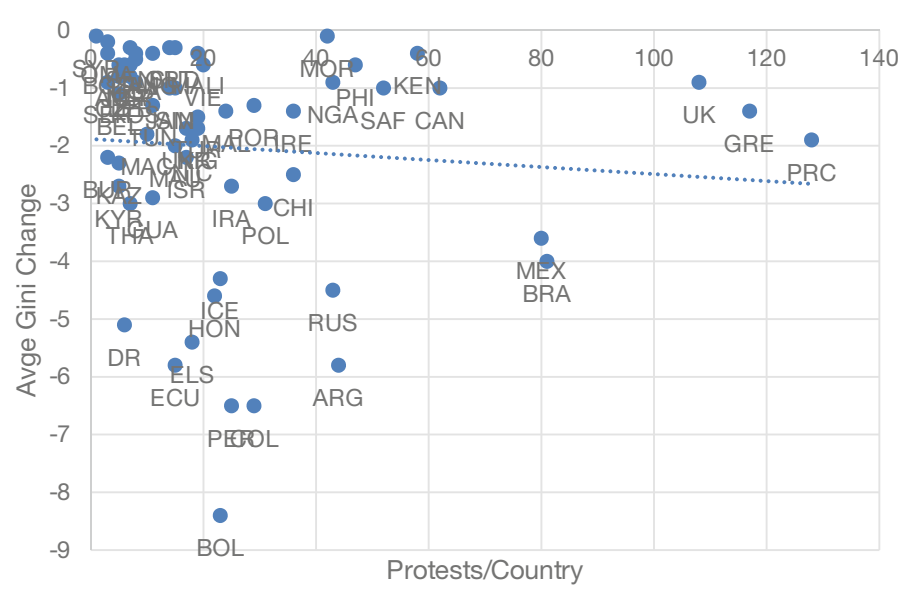

Fig. 6 Protests in countries with decreasing inequality, 2006-2020 (Source Authors' analysis of world protests in media sources 2006-2020 and Solt, 2020)

\subsection{Protests and the Perception That Governments Serve a Few}

Protestors target governments because they are the legitimate institutions that should respond to citizens. The extension of representative democracy as a form of government in the second part of the twentieth century meant that, for the first time in history, people around the world could choose the persons and policies in government. One result is that even in the very few countries without a liberal democratic regime, like the People's Republic of China, nonelected governments have been compelled to respond to the socio-economic needs of citizens.

Nevertheless, protestors have been dissatisfied with the results of democratic governments. The Economist Intelligence Unit (EIU) Democracy Index 2020 reveals a disjuncture between still-high levels of public support for democracy across the globe and deep popular disappointment with the functioning of democracy. In their view, there is a stagnation/recession of democracy-particularly in high-income countries - including: (i) an increasing emphasis on elite/expert governance rather than popular participatory democracy; (ii) a growing influence of unelected, unaccountable institutions and expert bodies; (iii) the removal of substantive issues of national importance from the political arena to be decided by politicians, experts, or supranational bodies behind closed 


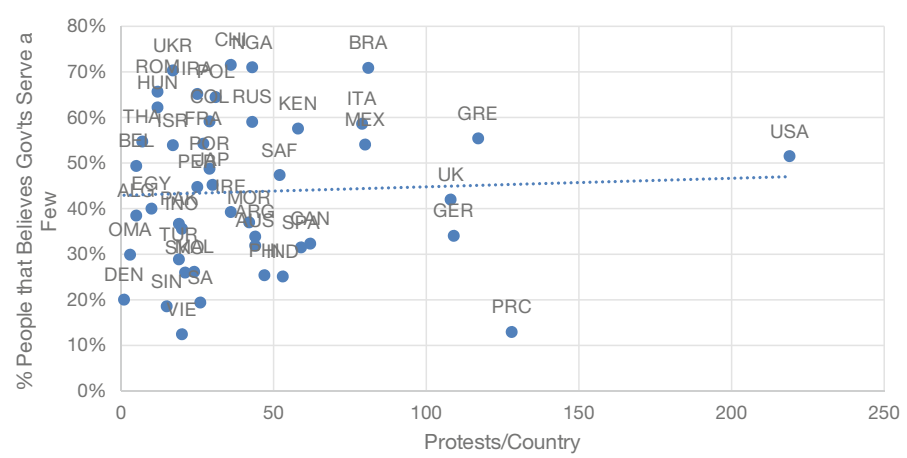

Fig. 7 Protests and the perception that governments serve the few (Source Authors' analysis of world protests in media sources 2006-2020 and Alliance of Democracies \& Dalia Research, 2020)

doors; (iv) a widening gap between political elites and parties on the one hand and national electorates on the other; and (v) a decline in civil liberties, including media freedom and freedom of speech (Economist Intelligence Unit, 2020: 6). This is much in accordance with our analysis, with the rise of protests for real democracy and against decisions taken behind closed doors by unaccountable bodies such as the European Union, the IMF, and the G20, as well as protests against the influence of elites and corporations on politics.

The perception that governments are coopted and serve the few (the elites, corporations, unaccountable institutions) instead of serving the majority of citizens is also corroborated by data published by the Alliance of Democracies and Dalia Research (2020) for their Democracy Perception Index. Figure 7 shows a correlation between the percentage of people who believe that governments serve the few, and the number of protests per country.

\section{Protesting Against Corruption}

Corruption is present in 558 protest-episodes (19.9\% of all protests analyzed), being the second most important tag overall after"Real Democracy" It has thus been one of the defining issues of the international agenda during the last 15 years, as protests against corruption increased over the period 2006-2020 (Fig. 8). 


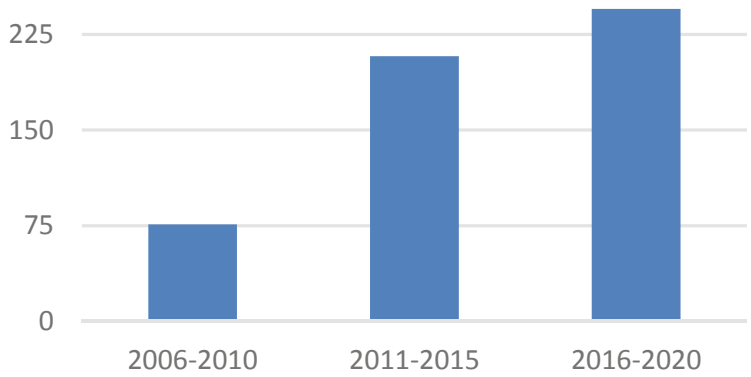

Fig. 8 Protests against corruption, 5-year periods, 2006-2020 (Source Authors' analysis of world protests in media sources 2006-2020 see: https://worldprot ests.org/)

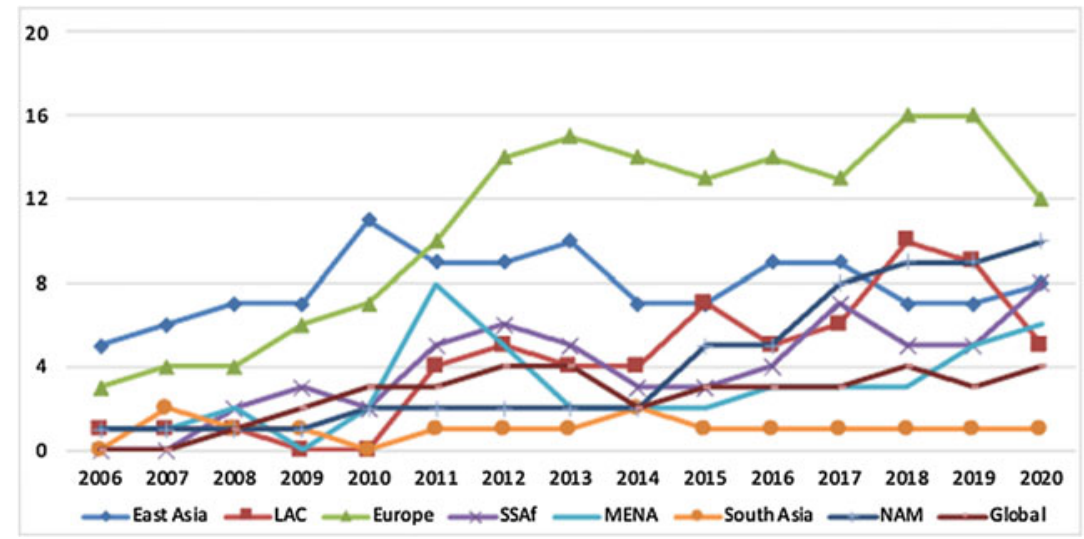

Fig. 9 Protests against corruption per region, 2006-2020 (Source Authors' analysis of world protests in media sources 2006-2020 see: https://worldprot ests.org/)

Protests against corruption are present in all world regions (see Fig. 9), although they are more prevalent in Europe and Central Asia. Many emblematic protests happened in this region, such as: those in Iceland (2010 and 2016); in Italy against the Mafia, Berlusconi, or the protests of 
the Sardines movement; or in Kyrgyzstan and Russia. Inside this region, it is in the Eastern European subregion where protests against corruption are more numerous. In Bosnia, Croatia, Bulgaria, Hungary, and Romania corruption and the issues of democracy and deep government are the core of several protests. The issue of corruption is also a key factor in the East Asian and Pacific region. Here there were important protests against corruption such as the ones in South Korea (2019), China-Macao (2006) and Hong Kong (2005).

Corruption is the second most prevalent grievance in protests occurring in middle-income countries-mainly upper-middle-income (318 protests). However, anti-corruption demands are also present in protests in high-income countries.

Both the regional analysis and the country-income analysis demonstrate that corruption is linked not only to developing societies-as it could readily be assumed-but also to high-income countries. The muchassumed causality between democracy and economic development ${ }^{7}$ is thus challenged by the importance attributed to corruption in countries with a high level of development. 8

Protests analyzed in this study tend to refer to a systemic/structural form of corruption rather than petty crime. This drives the concept towards the idea of political capture, reinforced as high levels of inequality are entrenched in societies and thus power is more and more concentrated in a few hands; this is, the capacity of some elites to influence the political game for their own benefit at the expense of the majority (Cortés Saenz \& Itríago, 2018). This grievance has been present in many protests, such as Algeria, Peru, France, and Kyrgyzstan. This perception of the elites (the $1 \%)$ rigging the system is also connected to the perception that democracy, or the system, is not serving the $99 \%$ of the population. Hence, the importance of "realdemocracy" as the main grievance in many of the protests analyzed (Fig. 10). This is reflected in the perception that the elites abuse their influence in the elaboration of public policies, whether

7 See: Friedman, M. with the assistance of Rose D. Friedman. 1962. Capitalism and Freedom. Chicago: The University of Chicago Press; North, Douglass C. 1990. Institutions, Institutional Change and Economic Performance. Cambridge: Cambridge University Press.

8 This could lead as well to discussions about how the level of development is measured. See: Costafreda, A., Maruri, E., Cortés Saenz, H. 2020. The triple challenge of the MICs countries in Latin America and the Caribbean. Development in Transition opportunities and the Agenda 2030. Oxfam Intermon Policy Brief. 


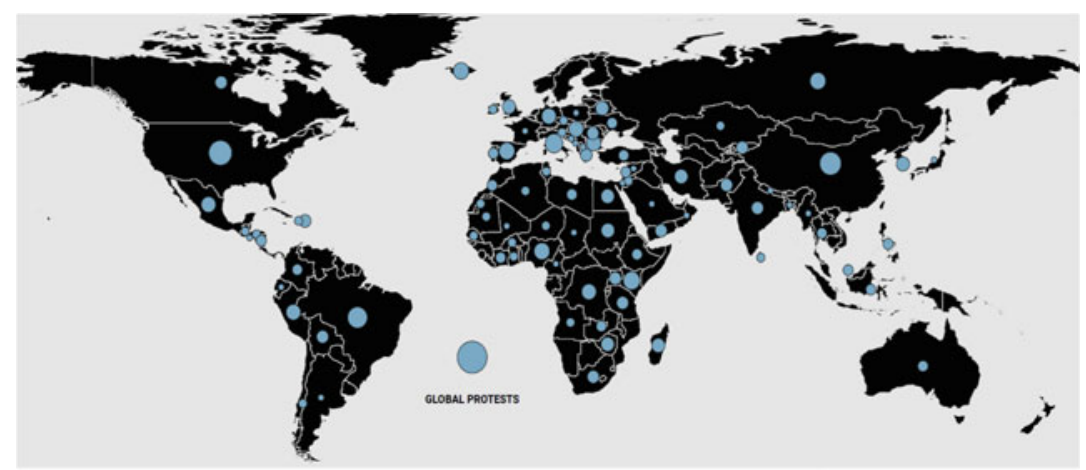

Fig. 10 Map of protests against corruption and for real democracy, 2006-2020 (Source https://worldprotests.org/)

in the concession of a mine (Bulgaria 2018), rigging elections (Macedonia, 2015), funding universities (Colombia 2019) or enacting energy policies (Nigeria 2012). One of the most paradigmatic examples is the Odebrecht scandal in which a construction company 'captured' different governments by financing election campaigns and bribing candidates in exchange for public infrastructure contracts. The revelations of the case sparked protests all over Latin America, especially in Peru (2017) and the Dominican Republic (2018). Finally, even though corruption is clearly linked to public civil servants, the role of transnational corporations, IFIs, and the consulting industry are also relevant and have been targeted in many anti-corruption protests.

\section{Fighting FOR Women's Rights}

Women's and girls' rights are an issue that has increased in importance year by year, with a significant spike from 2018 onwards (Fig. 11), and a cumulative total of 207 protest events for the 2006-2020 period as a whole.

This topic is of particular relevance in the Middle East and North Africa region, where this grievance is the third most numerous-after 'Real Democracy' and' 'Jobs/wages'-registering in 58 protest events. There are several examples of protests for women'srights that have become emblematic - with even global repercussions-and that have achieved 


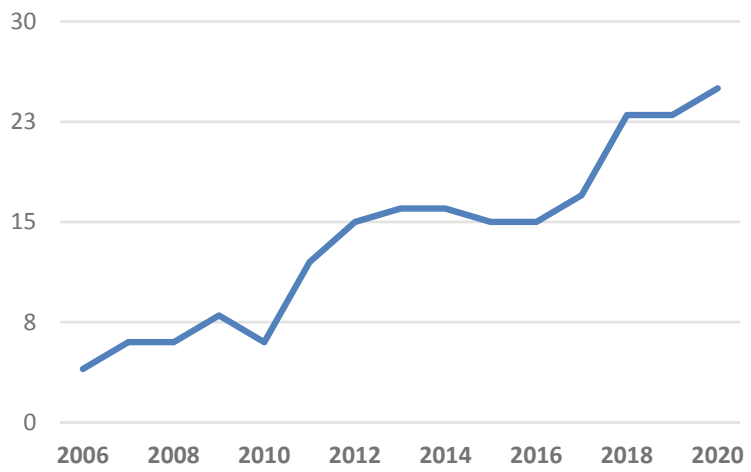

Fig. 11 Protests for women rights, 2006-2020 (Source Authors' analysis of world protests in media sources 2006-2020 see: https://worldprotests.org/)

their objectives after years of protests. Israel is one example with the protests against gender segregation in mehadrin bus lines; after many protests - and even diplomatic condemnations - a court ruled against it in 2011. In Saudi Arabia we find two important cases. The first one concerns the protests against the driving ban for women, starting in 2006 and lasting until the ban was removed in 2018. The second one pertains to demands for the right to vote, gained in 2015, when women were legally enabled to vote in local elections and be appointed to the Consultative Assembly.

Another important trend this research shows is the increasing importance of wome"srights protests. Women's movements have become more visible and powerful, which has transformed the International Women's Day into a massive global event. Global solidarity around women's and girls' rights has become an important element of the current context helping to raise the pressure in favor of their rights everywhere. This has been the case in El Salvador with the abortion protests (2020); \#NiUnaMas in Chile (2018); or \#BringBackOurGirls after the kidnappings of Nigerian girls (2014). All of them became global protests due to the solidarity and connections between social movements, by which local victories are celebrated as a global victory, as happened with the recent passing of an abortion law in Argentina.

Finally, three more elements are worthy of mention. Firstly, even though women's rights protests usually use pacifist and traditional 
methods, the last years of analysis show the use of alternative methods. This is the case in: the recent protests in Mexico (2020) in which aggressive methods were used; the global \#MeToo movement (2017) that denounced sexual harassment and used legal action as an essential method; and FEMEN (2008) activists using their bodies as a protest method. Secondly, as was mentioned above, these protests achieve specific victories but they also demonstrate a broader achievement related to their impact on the social agenda. Lastly, this research differentiates for obvious reasons women'srights protests and LGBT/Sexual rights ones. However, if considered as a single category of protest, their overall importance would rise from 207 protest events to 338 in the period 2006-2020.

\section{From the Arab Spring to the Latin America Spring: Ignored Economic Demands Lead to Political Dissent}

On January 4, 2011, Mohamed Bouazizi set himself ablaze in a protest against bad living conditions. That fire took the entire Arab world by surprise. The shock was so strong that some of the regimes with the hardest grip on power fell, notably those of Tunisia, Libya, and Egypt, after they saw mass protests sometimes leading to armed insurrection. However, our study reveals that protests were common prior to the Arab Spring. In 2008 in Tunisia there was a massive strike by the miners of Gafsa. For over 15 years, Rabat in Morocco experienced demonstrations by unemployed youth. In Egypt in 2007 and 2008 massive demonstrations by textile workers took place. Even in the United Arab Emirates, which experienced little to no protest during the Arab Spring itself, we find a large strike by construction workers in 2007 demanding higher wages.

By the end of 2019, a slew of demonstrations in Latin America started to be dubbed the "Latin American Spring." These Latin American protests were not as present in the international media as the Arab Spring had been, in part because of the coronavirus pandemic; however, their impact was significant. In Peru a president was removed, and his replacement stepped down in under a week. In Ecuador and Nicaragua austerity policies were rolled back due to popular pressure. In Chile people demonstrated and voted overwhelmingly in a national plebiscite to establish a 
new constitution. Mass movements occurred all over the South America, from Haiti and the Dominican Republic to Brazil and Argentina.

As in the Arab Spring, this was not a sudden change. Our research shows that protestors were as active prior to the Springs in both the Middle East and North Africa and in Latin America. Just a year before, in 2018, farmers in Peru were protesting the very low price at which they had to sell their crops. In 2017 Mexicans were protesting hikes in energy prices. People in Chile had been protesting against education reforms, privatization of pensions, and low incomes, among many other issues.

Our analysis shows that in the 2010-2014 period protestors primarily demonstrated for economic justice and against anti-austerity cuts. However, when their grievances were ignored, frustration set in due to the lack of jobs, inadequate social protection, poor public services, et cetera, such that protests turned more political. These failures of governments led toa new wave of protests starting in 2016-2017. The trend manifests itself in the Middle East and North Africa and in Latin America but is to be found in every region (see Fig. 12a-g).

In the Middle East and North Africa this tendency is even observed twice: there is a first inflection point in 2011 when failure of political representation protests begin to outnumber economic justice protests, then a second one in 2019, during what some observers have called the second Arab Spring. In both these instances protest events related to economic justice were very numerous, right up until protests against political failures exceeded them.

We can observe a global tendency for protest movements to push into the political arena when economic demands are left unanswered. The economic tensions that are voiced through protest should be taken seriously by policymakers, as they tend to evolve into a far less manageable and correctible collection of political demands, ${ }^{9}$ including demands for the potential downfall of governments, as was clearly seen during both the Arab and Latin American Springs.

${ }^{9}$ See Katz (1999). 
A - East Asia and Pacific

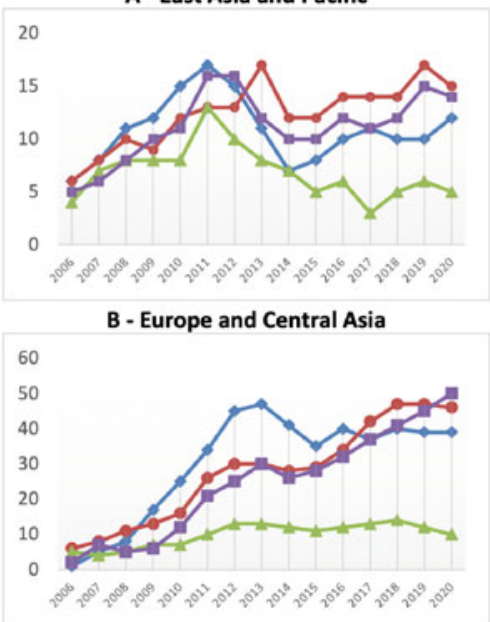

\section{C - Latin America and the Caribbean}

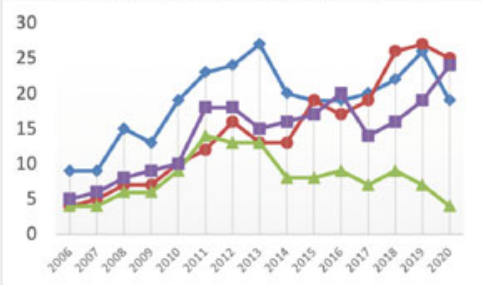

D - Middle East and North Africa

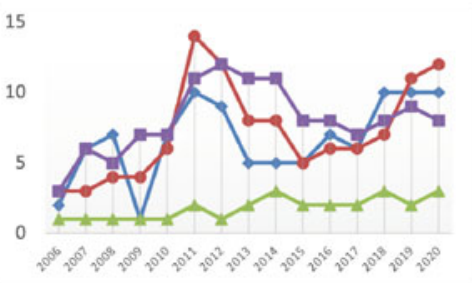

E - North America

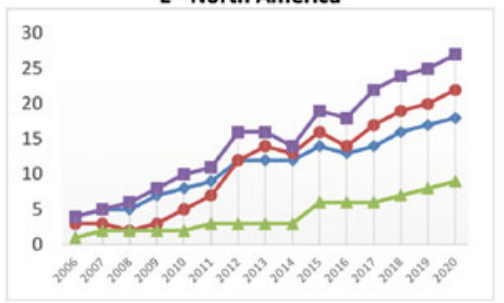

\section{F - South Asia}

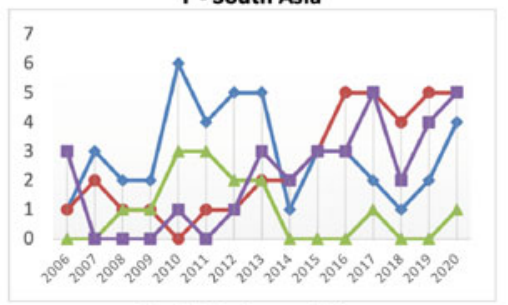

G - Sub Saharan Africa

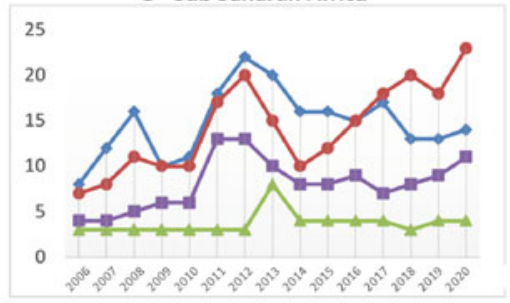

$\longrightarrow$ Economic Justice and Anti-austerity

$\multimap$ Failure of Political Representation

- Global Justice

- -Rights

Fig. 12 Main grievances per region 2006-2020 


\section{Protests, Human Rights and Development Policies: What Governments Can Do}

This book has analyzed the main protests that occurred between 2006 and 2020. It described who protests and why, and it looked at the numbers of protestors and their repression in terms of arrests, injuries, and deaths. Further the study has elaborated on methods of protests, presenting 250 methods of nonviolent protest. It also looked at the questions: who do protestors oppose, and what do they achieve? Lastly, it has analyzed a series of key topics such as the rise of radical right protests, inequality, anti-corruption and women rights' protests, and the Arab and Latin American Springs.

This section aims to offer some suggestions regarding what governments can do. Section 10 showed that governments are the most frequent target for protesters, by a wide margin-as the legitimate policy-making institution responsible to citizens. The perception that governments are coopted and serve the few (the elites, corporations, unaccountable institutions such as the G20, the IMF or the European Union) instead of serving the majority of citizens, is corroborated by recent polls and research presented earlier. Nearly $80 \%$ of all protests demand that governments take responsibility for economic, social, and environmental policies so that they benefit all, instead of the few.

Ultimately, the story of protests in the period 2006-2020 is one of frustrated citizens taking to the streets because their claims and demands were not met. As detailed in this book, protests are not random unorganized riots: the majority of protests are planned and their grievances are articulated, pointing to the failures of political and economic systems.

The set of policies needed at both national and global levels to address the grievances described in this study cross over into virtually every area of public policy, from jobs, public services, and social protection to good governance, civil rights, fair taxation and resources for national development. Table 1 identifies the main demands that protestors put to policymakers, in the order of their occurrence in world protests. The majority are in full accordance with Human Rights and internationally-agreed United Nations development goals.

States have obligations to respect and fulfill all Human Rights, including the right to protest, the rights to freedom of peaceful assembly and freedom of expression established in articles 21 and 19 respectively of 
Table 1 Main human rights and development policy demands from world protesters 2006-2020

\begin{tabular}{|c|c|c|c|}
\hline Demand/grievance & Times raised & Percent & $\begin{array}{l}\text { Human } \\
\text { rights/developmental policies }\end{array}$ \\
\hline Real democracy & 779 & 27.7 & $\begin{array}{l}\text { As part of good } \\
\text { governance, States and } \\
\text { policy-makers must serve } \\
\text { the interests of all citizens } \\
\text { (instead of the few, the } \\
\text { elites); participatory/direct } \\
\text { democracy }\end{array}$ \\
\hline Corruption & 558 & 19.9 & $\begin{array}{l}\text { The State (the 'duty-bearer' } \\
\text { of rights) must be at center } \\
\text { of the anti-corruption } \\
\text { debate and efforts at all } \\
\text { levels, prosecuting corrupt } \\
\text { practices and ensuring } \\
\text { systems that respond to } \\
\text { citizens }\end{array}$ \\
\hline Jobs/wages/labor conditions & 517 & 18.4 & $\begin{array}{l}\text { National and global } \\
\text { recovery strategies should } \\
\text { focus on } \\
\text { employment-generating } \\
\text { real-economy growth, } \\
\text { raising wages, social } \\
\text { protection, and living } \\
\text { standards to promote } \\
\text { socioeconomic } \\
\text { development, in accordance } \\
\text { with international labor } \\
\text { standards }\end{array}$ \\
\hline Reform of public services & 478 & 17.0 & $\begin{array}{l}\text { Stop reforms based on fiscal } \\
\text { cost-savings; the State must } \\
\text { guarantee the right to food, } \\
\text { water, housing, health, } \\
\text { education, social security, } \\
\text { and all other Human Rights }\end{array}$ \\
\hline $\begin{array}{l}\text { Corporate influence/ } \\
\text { Deregulation/privatization }\end{array}$ & 418 & 14.9 & $\begin{array}{l}\text { As part of good } \\
\text { governance, stop } \\
\text { rent-seeking practices; } \\
\text { promote adequate public } \\
\text { services; public institutions } \\
\text { must respond to priorities } \\
\text { of all citizens instead of } \\
\text { prioritizing the private } \\
\text { interests of corporations }\end{array}$ \\
\hline
\end{tabular}


Table 1 (continued)

\begin{tabular}{|c|c|c|c|}
\hline Demand/grievance & Times raised & Percent & $\begin{array}{l}\text { Human } \\
\text { rights/developmental policies }\end{array}$ \\
\hline Justice & 410 & 14.6 & $\begin{array}{l}\text { States and policymakers to } \\
\text { ensure that national judicial } \\
\text { systems enforce justice for } \\
\text { all, without discrimination }\end{array}$ \\
\hline $\begin{array}{l}\text { Ethnic/indigenous/ } \\
\text { racial justice }\end{array}$ & 396 & 14.1 & $\begin{array}{l}\text { States must protect the } \\
\text { rights of racial minorities } \\
\text { and indigenous peoples }\end{array}$ \\
\hline Environment/climate Justice & 359 & 12.8 & $\begin{array}{l}\text { Policymakers to effectively } \\
\text { redress climate change and } \\
\text { support the environment; } \\
\text { to solve conflicts related to } \\
\text { infrastructure construction } \\
\text { with negative social and } \\
\text { environmental externalities; } \\
\text { to use environmentally } \\
\text { friendly forms of energy; to } \\
\text { secure adequate } \\
\text { taxation/public revenues } \\
\text { from natural resource } \\
\text { extraction }\end{array}$ \\
\hline Inequality & 347 & 12.4 & $\begin{array}{l}\text { Policymakers must put an } \\
\text { end to gross economic } \\
\text { inequalities as well as other } \\
\text { inequalities (e.g., ethnicity/ } \\
\text { race, gender, etc.) as } \\
\text { established by Human } \\
\text { Rights and other } \\
\text { international standards }\end{array}$ \\
\hline Tax/fiscal justice & 339 & 12.1 & $\begin{array}{l}\text { Policy makers to raise fair } \\
\text { taxes from wealthy } \\
\text { individuals, groups and } \\
\text { corporations (e.g., personal } \\
\text { and corporate income and } \\
\text { wealth taxes, including on } \\
\text { the financial sector), fight } \\
\text { tax fraud and tax evasion } \\
\text { and crack down on tax } \\
\text { havens; stop/reverse } \\
\text { transfers and bailouts to the } \\
\text { financial } \\
\text { sector/corporations; stop } \\
\text { austerity cuts that negatively } \\
\text { affect populations; lower } \\
\text { consumption taxes/VAT on } \\
\text { products that low-income } \\
\text { people consume }\end{array}$ \\
\hline
\end{tabular}


Table 1 (continued)

\begin{tabular}{|c|c|c|c|}
\hline Demand/grievance & Times raised & Percent & $\begin{array}{l}\text { Human } \\
\text { rights/developmental policies }\end{array}$ \\
\hline $\begin{array}{l}\text { Anti-international financial } \\
\text { institutions (IMF, World } \\
\text { Bank, regional banks) }\end{array}$ & 319 & 11.4 & $\begin{array}{l}\text { The IFIs should not apply } \\
\text { conditionalities, particularly } \\
\text { those undermining Human } \\
\text { Rights and international } \\
\text { labor and environmental } \\
\text { standards such as those } \\
\text { based on the Washington } \\
\text { Consensus, minimizing the } \\
\text { public sector, promoting } \\
\text { liberalization, deregulation, } \\
\text { and privatization; current } \\
\text { IFIs should be reformed or } \\
\text { new institutions be put in } \\
\text { place to promote Human } \\
\text { Rights, equitable and } \\
\text { sustainable development for } \\
\text { all }\end{array}$ \\
\hline Rights to the commons & 299 & 10.6 & $\begin{array}{l}\text { Preserve and ensure } \\
\text { universal access to the } \\
\text { commons (digital, water, } \\
\text { cultural, atmospheric) }\end{array}$ \\
\hline Low living standards & 283 & 10.1 & $\begin{array}{l}\text { States and policymakers to } \\
\text { end poverty and raise living } \\
\text { standards, including with } \\
\text { better jobs, wages, and } \\
\text { social protection benefits in } \\
\text { accordance with } \\
\text { international standards and } \\
\text { Human Rights }\end{array}$ \\
\hline Sovereignty/patriotic issues & 264 & 9.4 & $\begin{array}{l}\text { While collaboration on } \\
\text { global matters is necessary, } \\
\text { policy-making must focus } \\
\text { on serving the interest of } \\
\text { their citizens first }\end{array}$ \\
\hline Anti-imperialism & 263 & 9.4 & $\begin{array}{l}\text { World/regional powers } \\
\text { must stop interference in } \\
\text { national policy-making of } \\
\text { weaker nations; respect } \\
\text { national sovereignty; stop } \\
\text { wars and military } \\
\text { intervention }\end{array}$ \\
\hline $\begin{array}{l}\text { Transparency and } \\
\text { accountability }\end{array}$ & 244 & 8.7 & $\begin{array}{l}\text { As part of good } \\
\text { governance, States and } \\
\text { policy-makers must enforce } \\
\text { transparent and accountable } \\
\text { processes and institutions } \\
\text { that respond to people }\end{array}$ \\
\hline
\end{tabular}


Table 1 (continued)

\begin{tabular}{|c|c|c|c|}
\hline Demand/grievance & Times raised & Percent & $\begin{array}{l}\text { Human } \\
\text { rights/developmental policies }\end{array}$ \\
\hline Deep government/Oligarchy & 211 & 7.5 & $\begin{array}{l}\text { As part of good } \\
\text { governance, States } \\
\text { policy-makers must stop the } \\
\text { influence of any vested } \\
\text { interest/groups on } \\
\text { government and serve the } \\
\text { interests of all persons }\end{array}$ \\
\hline $\begin{array}{l}\text { Freedom of } \\
\text { assembly/speech/press }\end{array}$ & 208 & 7.4 & $\begin{array}{l}\text { States and policy-makers } \\
\text { must ensure the right to } \\
\text { assembly, freedom of speech } \\
\text { and press }\end{array}$ \\
\hline Women's/girls' rights & 207 & 7.4 & $\begin{array}{l}\text { Women are half of the } \\
\text { world population but do } \\
\text { not benefit equally from } \\
\text { policies; States and } \\
\text { policymakers to promote } \\
\text { and enforce gender equality }\end{array}$ \\
\hline Labor rights & 199 & 7.1 & $\begin{array}{l}\text { States and policymakers to } \\
\text { promote and protect labor } \\
\text { rights to allow workers and } \\
\text { their families to live in } \\
\text { dignity, in accordance with } \\
\text { international labor standards }\end{array}$ \\
\hline Agrarian/land reform & 181 & 6.4 & $\begin{array}{l}\text { States and policymakers to } \\
\text { redress inequalities in } \\
\text { landownership and land use } \\
\text { to allow for decent incomes } \\
\text { in rural areas }\end{array}$ \\
\hline $\begin{array}{l}\text { Anti-war/military-industrial } \\
\text { complex }\end{array}$ & 181 & 6.4 & $\begin{array}{l}\text { States and policymakers to } \\
\text { enforce the right to peace, } \\
\text { stop wars and military } \\
\text { interventions; reduce arms } \\
\text { trade; rent-seeking practices } \\
\text { by the military-industrial } \\
\text { complex must be forbidden }\end{array}$ \\
\hline Fuel and energy prices & 136 & 4.8 & $\begin{array}{l}\text { Policymakers to ensure } \\
\text { affordable and sustainable } \\
\text { energy to populations }\end{array}$ \\
\hline LGBT/Sexual Rights & 131 & 4.7 & $\begin{array}{l}\text { States to promote and } \\
\text { respect lesbian, gay, bisexual } \\
\text { and transgendered rights; } \\
\text { sexual orientation is a } \\
\text { personal choice that must } \\
\text { be the sole decision of the } \\
\text { person involved without } \\
\text { external coercion }\end{array}$ \\
\hline
\end{tabular}


Table 1 (continued)

\begin{tabular}{|c|c|c|c|}
\hline Demand/grievance & Times raised & Percent & $\begin{array}{l}\text { Human } \\
\text { rights/developmental policies }\end{array}$ \\
\hline Immigrant rights & 121 & 4.3 & $\begin{array}{l}\text { States to promote and fulfill } \\
\text { immigrants' rights }\end{array}$ \\
\hline Citizen surveillance & 103 & 3.7 & $\begin{array}{l}\text { Governments to stop } \\
\text { surveillance/spying on } \\
\text { citizens and restricting the } \\
\text { Internet }\end{array}$ \\
\hline Pension reform & 97 & 3.5 & $\begin{array}{l}\text { States and policymakers to } \\
\text { stop pension reforms driven } \\
\text { by cost-savings and } \\
\text { pressures from private } \\
\text { insurance lobbies to } \\
\text { privatize; focus instead on } \\
\text { improving public systems to } \\
\text { sustainably and equitably } \\
\text { provide old-age income } \\
\text { security in accordance with } \\
\text { international standards }\end{array}$ \\
\hline Anti-free trade & 96 & 3.4 & $\begin{array}{l}\text { Policymakers to stop the } \\
\text { drive to free trade } \\
\text { agreements that hinder } \\
\text { national productive } \\
\text { capacities and employment }\end{array}$ \\
\hline Housing & 85 & 3.0 & $\begin{array}{l}\text { States and policymakers to } \\
\text { stop evictions and fulfill the } \\
\text { right to housing }\end{array}$ \\
\hline Prisoners' rights & 75 & 2.7 & $\begin{array}{l}\text { States to promote and } \\
\text { respect rights of prisoners }\end{array}$ \\
\hline Food prices & 73 & 2.6 & $\begin{array}{l}\text { States and policymakers to } \\
\text { fulfill the right to food }\end{array}$ \\
\hline Global commons & 71 & 2.5 & $\begin{array}{l}\text { Ensure good } \\
\text { governance/stewardship of } \\
\text { the global commons e.g., } \\
\text { internet, climate, } \\
\text { biodiversity }\end{array}$ \\
\hline Religious rights & 71 & 2.5 & $\begin{array}{l}\text { Religious freedom needs to } \\
\text { be guaranteed in its various } \\
\text { expressions }\end{array}$ \\
\hline Anti-G20 & 37 & 1.3 & $\begin{array}{l}\text { The G20 (or the G8) are } \\
\text { non-legitimate and } \\
\text { non-democratic } \\
\text { organizations that should } \\
\text { not set policies that } \\
\text { interfere with other nations' } \\
\text { development and Human } \\
\text { Rights achievements }\end{array}$ \\
\hline
\end{tabular}


the International Covenant on Civil and Political Rights (United Nations, 2013). Peaceful protests are a fundamental aspect of a vibrant democracy. Historically, protests have been a means to achieve fundamental rights at the national and international level (Tilly, 1978; United Nations, 2012).

Governments need to listen to the messages coming from protesters, whether well-articulated or not, and act on them. The demands from protestors are often well-established development policies, agreed by all countries at the United Nations and in their national development strategies. A real transformation is required beyond calls for "policy shifts" and "building back better," which are by now standard buzzwords of the world's governments and intergovernmental organizations. Leaders and policymakers will only invite further unrest if they fail to prioritize and act on protestors' demands.

\section{REFERENCES}

Alliance of Democracies \& Dalia Research. (2020). Democracy Perception Index 2020. Dalia Research. Available at https://daliaresearch.com/blog/democr acy-perception-index-2020/. Last accessed 24 May 2021.

Bello, W. (2019). Counterrevolution: The global rise of the far right. Practical Action Publishing.

Brannen, S., Haig, C., \& Schmidt, K. (2020). The age of mass protests: Understanding an escalating global trend. Center for Strategic and International Studies (CISS).

Bröning, M. (2016, June 3). The rise of populism in Europe: Can the center hold? Foreign Affairs.

Collier, P., \& Hoeffler, A. (2004). Greed and grievance in civil war. Oxford Economic Papers-New Series, 56(4), 563-595.

Cortés Saenz, H., \& Itríago, D. (2018). The capture phenomenon: unmasking power. Oxfam Intermon. Available at https://web.oxfamintermon.org/sites/ default/files/documentos/files/ENG_Oxfam_Intermon_Capture_Methodo logy_2018.pdf. Last accessed 24 May 2021.

della Porta, D. (Ed.) (2017). Global diffusion of protest: Riding the protest wave in the neoliberal crisis. Amsterdam University Press.

Dubrow, J., Slomczynski, K., \& Tomescu-Dubrow, I. (2008). Effects of democracy and inequality on soft political protest in Europe: Exploring the European social survey data. International Journal of Sociology, 38(3), 36-51.

Economist Intelligence Unit (EIU). (2020). Democracy Index 2019 A year of democratic setbacks and popular protest. The Economist. 
Foa, R.S., Klassen, A., Slade, M., Rand, A., \& Collins, R. (2020). The global satisfaction with democracy report 2020. Centre for the Future of Democracy. Available at https://www.bennettinstitute.cam.ac.uk/media/uploads/ files/DemocracyReport2020_nYqqWi0.pdf. Last accessed 24 May 2021.

Frank, T. (2020). The people, no! A brief history of anti-populism. Metropolitan Books, Henry Holt and Company.

Katz, M. (1999). Revolutions and revolutionary waves. Macmillan.

MacCulloch, R. (2005). Income inequality and the taste for revolution. Journal of Law \& Economics, 48(1), 93-123.

Organization for Economic Co-operation and Development (OECD). (2019). Under pressure: The squeezed middle class. Overview and main findings. Organisation for Economic Co-operation and Development.

Ortiz, I., Burke, S., Berrada, M., \& Cortes-Saenz, H. (2013). World Protests 2006-2013. IPD Columbia University and Friedrich-Ebert-Stiftung. Available at http://policydialogue.org/files/publications/World_Protests_2006-2013Complete_and_Final_4282014.pdf. Last accessed 24 May 2021.

Ortiz, I., \& Cummins, M. (2019). Austerity, the new normal: A renewed Washington Consensus 2010-24. New York, Brussels and Washington, DC: Initiative for Policy Dialogue, International Confederation of Trade Unions, Public Services International, EURODAD and Bretton Woods Project. Available at http://policydialogue.org/files/publications/papers/Austeritythe-New-Normal-Ortiz-Cummins-6-Oct-2019.pdf. Last accessed 13 April 2021.

Oxfam. (2020). Time to care: Unpaid and underpaid care work and the global inequality crisis. Oxfam International. Available at https://oxfamilibrary.ope nrepository.com/bitstream/handle/10546/620928/bp-time-to-care-inequa lity-200120-en.pdf. Last accessed 24 May 2021.

Oxfam. (2021). The inequality virus: Bringing together a world torn apart by coronavirus through a fair, just and sustainable economy. Oxfam International. Available at https://oxfamilibrary.openrepository.com/bitstream/han dle/10546/621149/bp-the-inequality-virus-250121-en.pdf. Last accessed 24 May 2021.

Rohac, D., Kennedy, L., \& Singh, V. (2018). Drivers of authoritarian populism in the United States: A primer. Center for American Progress.

Solt, F. (2020, October). Measuring income inequality across countries and over time: The standardized world income inequality database. Social Science Quarterly, 101(3), 1183-1199. SWIID Version 9.0.

Tilly, C. (1978). From mobilization to revolution. Addison-Wesley.

United Nations. (2012). Report of the United Nations Special Rapporteur on the rights to freedom of peaceful assembly and association. UN Human Rights Council A/HRC/20/27. 
United Nations. (2013). Effective measures and best practices to ensure the promotion and protection of human rights in the context of peaceful protests. Human Rights Council Resolution A/HRC/22/28.

United Nations. (2020). World social report 2020: Inequality in a rapidly changing world. United Nations Department of Economic and Social Affairs.

Open Access This chapter is licensed under the terms of the Creative Commons Attribution 4.0 International License (http://creativecommons.org/licenses/ by $/ 4.0 /$ ), which permits use, sharing, adaptation, distribution and reproduction in any medium or format, as long as you give appropriate credit to the original author(s) and the source, provide a link to the Creative Commons license and indicate if changes were made.

The images or other third party material in this chapter are included in the chapter's Creative Commons license, unless indicated otherwise in a credit line to the material. If material is not included in the chapter's Creative Commons license and your intended use is not permitted by statutory regulation or exceeds the permitted use, you will need to obtain permission directly from the copyright holder.

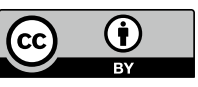

